PERM JOURNAL OF PETROLEUM AND MINING ENGINEERING ВЕСТНИК ПНИПУ. ГЕОЛОГИЯ. НЕФТЕГАЗОВОЕ И ГОРНОЕ ДЕЈО

ISSN 2224-9923

Volume / Том 17 №1 2018

http://vestnik-pstu.ru/geo/

УДК 622.814-047.37

Article / Статья

(C) PNRPU / ПНИПУ, 2018

\title{
METHODOLOGY FOR INVESTIGATION OF STONE DUST COMBUSTION AND DETONATION PROCESSES IN MINING
}

\section{Vladimir A. Rodionov, Zaur A. Abiev ${ }^{1}$, Sergey Ya. Zhikharev ${ }^{2}$}

Saint Petersburg University of State Fire Service of EMERCOM of Russia (149 Moskovskiy av., Saint Petersburg, 196105, Russian Federation) ${ }^{1}$ Saint-Petersburg Mining University (2 $21^{\text {st }}$ Line, Vasilyevskiy island, Saint Petersburg, 199106, Russian Federation)

${ }^{2}$ Mining Institute of the Ural Branch of the Russian Academy of Sciences (78 Sibirskaya st., Building A, Perm, 614007, Russian Federation)

\section{МЕТОДИКА ИССЛЕДОВАНИЯ ПРОЦЕССОВ ГОРЕНИЯ И ДЕТОНАЦИИ КАМЕННОУГОЛЬНОЙ ПЫЛИ В ГОРНЫХ ВЫРАБОТКАХ}

\section{В.А. Родионов, 3.А. Абиев ${ }^{1}$, С.Я. Жихарев ${ }^{2}$}

Санкт-Петербургский университет государственной противопожарной службы МЧС РФ

(196105, Россия, г. Санкт-Петербург, Московский пр., 149)

${ }_{2}^{1}$ Санкт-Петербургский горный университет (199106, Россия, г. Санкт-Петербург, Васильевский остров, 21-я линия, 2)

${ }^{2}$ Горный институт Уральского отделения Российской академии наук (614007, Россия, г. Пермь, ул. Сибирская, 78a)

Received / Получена: 27.11.2017. Accepted / Принята: 12.02.2018. Published / Опубликована: 30.03.2018

Key words:

explosion, explosion pressure increase rate, coal dust, explosion pressure, combustion, aerosol, deflagration, detonation.

\begin{abstract}
The paper presents results of the study of processes of coal dust detonation combustion obtained using a technique approved by the authors. The essence of the technique is the use of a specific coal dust fraction to study the explosion pressure, explosion pressure increase rate and transformation coefficient. It allows applying the results of a laboratory experiment to the actual data of explosion and combustion of dust and gas mixtures of mines that have a much larger volume. In other words it allows predicting the explosion pressure increase rate in relation to specific excavation of coal mines.

The methodology for studying combustion and detonation processes, briefly described in the article, is based both on requirements of modern regulatory documents and the practical experience of research institutes engaged in similar requirements of modern regulatory documents and the practical experience of research institutes engaged in similar
research. The practical component of the method is based on an installation which represents an explosive combustion research. The practical component of the method is based
chamber in the form of a sphere with a volume of 20 liters.

The data of detonation combustion are processed using application software and presented graphically in three figures. It is shown that The data of detonation combustion are processed using application software and presented graphically in three figures. It is shown that
dispersion composition of coal dust indluences on the explosion pressure, explosion pressure increase rate and transformation coefficient.

dispersion composition of coal dust indluences on the explosion pressure, explosion pressure increase rate and transformation co As a result of the analysis of digital and graphic data obtained during processing, it is proved that dust with fractional composition of $63-$ $94 \mu \mathrm{m}$ is the most explosive. It is revealed that explosion pressure increase rate changes as a function of dust concentration in the installation reaction volume in the way that there was two maxima of the explosion pressure increase rate where one was at $100 \mathrm{~g} / \mathrm{m}^{3}$ and the second at $400 \mathrm{~g} / \mathrm{m}^{3}$. The results obtained during determination of the explosion pressure increase rate have shown the necessity of a non-trivial, more thoroughtful approach to study explosion pressure increase and, consequently, determin the transformation coefficient. In addition, analysis of the experimental data presented in the article confirmed that during the development of means of flame retardation and explosion suppression used in automatic means for explosion localization it is necessary to carry out further investigations with the coal dust fraction equal to 63-94 $\mu \mathrm{m}$. The results obtained in the work will allow starting the study of the processes of detonation combustion in a dusty air containing methane.
\end{abstract}

Приведены результаты исследования процессов детонационного горения каменноугольной пыли, полученные с помощью апробированной авторами методики, сущность которой заключается в использовании конкретной фракции каменноугольной пыли для исследования давления взрыва, скорости нарастания давления взрыва и трансформационного коэффициента. Он позволяет применить результаты лабораторного эксперимента к фактическим данным взрыва и горения пылегазовоздушных смесей горных выработок, имеющих значительно больший объем, т.е. дает возможность спрогнозировать скорость нарастания давления взрыва применительно к конкретным горным выработкам угольных шахт.

Методика исследования процессов горения и детонации, кратко описанная в статье, основана как на требованиях современных нормативно-правовых документов, так и на практическом опыте научно-исследовательских институтов, занимающихся аналогичными исследованиями. В основу практической составляющей методики положена установка, представляющая собой взрывную камеру сгорания в виде сферы объемом 20 л.

положена установка, представляющая собой взрывную камеру сгорания в виде сферы объемом 20 л. Данные процесса детонационного горения обработаны с помощью прикладного программного обеспечения и представлены в графическом виде на трех рисунках. Наглядно показано влияние дисперсионного состава каменноугольной Пыли на давление взрыва, скорость нарастания давления при взрыве и трансформационный коэффициент. Н

работа проводилась с образцом каменного угля марки КС, пласт Мощный, шахта им. Дзержинского. В результате анализа цифровых и графических данных, полученных в ходе обработки, доказано, что наиболее эффект изменения скорости нарастания давления взрыва в зависимости от концентрации пыли в реакционном объеме установки, а именно наблюдалось два максимума скорости нарастания давления взрыва, один при 100 г/м и второй при $400 \mathrm{r} / \mathrm{m}^{3}$. Полученные результаты определения скорости нарастания давления взрыва показали необходимость нетривиального, более тщательного подхода к ее исследованию и, как следствие, к определению трансформационного коэффициента. Кроме того, анализ экспериментальных данных, приведенных в настоящей статье, подтвердил, что при разработке эффективных средств огнепреграждения и взрывоподавления, применяемых в автоматических средствах локализации взрыва, необходимо проводить дальнейшие исследования с фракцией каменноугольной пыли, равной 63-94 мкм. Полученные в работе результаты позволят перейти к изучению процессов детонационного горения в пылевоздушной среде содержащей метан.

The contact person for correspondence.

Sergey Ya. Zhikharev - Doctor of Engineering, Senior Research Fellow (mob. tel.: +007921 32583 97, e-mail: perevoloki55@mail.ru).

Родионов Владимир Алексеевич - докторант факультета подготовки кадров высшей квалификации (моб. тел.: +007 921 325 83 97, e-mail: $79213258397 @$ mail.ru). Контактное лицо для переписки.

Абиев Заур Агаддович - аспирант кафедры взрывного дела (моб. тел.: +007921 39394 89, e-mail: abievzaur@gmail.com)

Жихарев Сергей Яковлевич - доктор технических наук, главный научный сотрудник (моб. тел.: +007 921 325 83 97, e-mail: perevoloki55@mail.ru) 


\section{Introduction}

Control of methane and coal dust explosions is one of the most urgent problems of ensuring safe working conditions in coal mines. It is known that in the case of a poor state of dust explosion protective devices even local explosions of methane or suspended coal dust that happen in a place of mine workings can spread over a considerable distance [1-5].

In recent years, dust formation and volume of gas in mine working increased sharply due to intensification of coal mining and complicated mining, geological and technical conditions. That has led to a high danger of explosions [2, 6-10].

The scientific and technical information given in $[10,11]$, as well as the factors mentioned above, confirm the need to timely determine the detonation properties of coal dust, formed in the current conditions of coal mining. After, it is necessary to scientifically substantiate the screening for devices of explosion damaging factors suppression (flame front/ shock wave etc.), including high effectiveness fire extinguishing/explosion suppression devices $[9,11]$.

The purpose of the paper is to study the processes of combustion and detonation of coal dust in mine workings to determine the maximum explosion pressure, explosion pressure increase rate and transformation coefficient, which allows correlating the results of laboratory studies with mine space.

\section{Object of the study}

The object of the study are KS-type coal samples from the Moshchny seam of mine named after Dzerzhinskiy, which is classified as super dangerous in terms of dust and gas. The seam Moshchny refers to a very prone to spontaneous self-combustion. There is a minimum yield of volatile substances in coals of all strata in the mine field equal to $17.3 \%$. According to the
"General safety rules", dust with the release of volatile substances of more than $10 \%$ is explosive one $[10,12]$.

Samples of fractional composition of 63-94 $\mu \mathrm{m}$ were used when performing a study of combustion processes and detonation properties of coal dust. Screening for that fractional composition is not accidental and is explained by the data given in $[10,13-17]$, where it is shown coal dust of that fractional composition is the most explosive and is formed in a larger amount during the coal mining (with its grinding).

\section{Methods and procedures of the study}

The study is performed usign an approved method by the authors of the article decribed in [13, 18]. Results of the study are presented in this article. In addition, requirements and recommendations on how to apply methods for assessing the explosive and fire hazard properties of coal dust aerosols described in the works of other authors [14, 19-26] are taken into account.

Laboratory studies of the processes of detonation combustion of coal dust air aerosol were carried out on an installation made on the basis of an Austrian license by the Institute of Industrial Explosion Protection (China), built at the Saint-Petersburg Mining University.

The installation is shown in Fig. 1.

The procedure (general algorithm) for carrying out the laboratory study is as follows: an aerosol of coal dust is injected at a single moment by compressed air at pressure of $2 \mathrm{MPa}$ to the closed combustion chamber of the installation shown in Fig. 1.

The main technological operations in the tests are given below:

- sample preparation (grinding of coal to the working fraction, i.e. grinding on a vibratory cone mill-crusher; VKMD-10 was used)

- granulometric sieving (obtaining the required fraction with the particle size of sand dust in the range of $63-94 \mu \mathrm{m})$; 
- air-dry drying;

- sampling by quarting for weighing and obtaining the required sample mass;

- loadng of the sand dust sample into the boot device of the installation;

- testing according the installation manual and authors' data [24, 25].

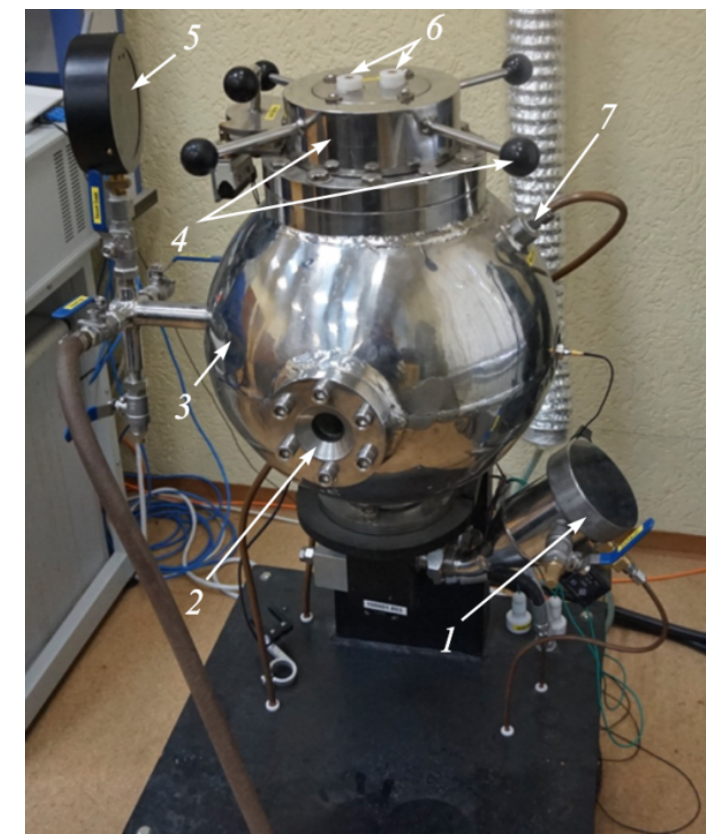

Fig. 1. The installation: 1 - feeding device (dust collector with a volume of $\left.0.6 \mathrm{dm}^{3}\right) ; 2$ - inspection window; 3 - working chamber with an internal volume of 20 liters; 4 - holders and locking mechanism of the 20-liter sphere (working chamber); 5 - manometer; 6 - current conductors (holders of a chemical combustion); 7 - water outlet

According to the methods described in [1921], it is recommended to carry the ignition of the dust-air mixture with a delay of $60 \mathrm{~ms}$.

Considering the recommendations given in [22, 23], a composition of $2.4 \mathrm{~g}$ was chosen as chemical igniter.

A zirconium powder, nitrate and barium oxide were used as the main components of chemical igniters. There were two igniters simultaneously used in the installation. The igniters allowed obtaining a total energy of $10 \mathrm{~kJ}$.

The pressure created by two such ignitors was $0.19 \pm 0.01 \mathrm{MPa}$. Results of ignition of the formed inside the working chamber of a coal dust aerosol of a given concentration (in particular the explosion pressure and rate of explosion pressure increase) were automatically fixed by the data processing system.

After the test, a graph with dynamics of pressure changes in the volume of a 20-liter sphere (an explosive chamber) was analyzed. As for example Fig. 2 shows the test schedule for the explosive characteristics of one of the coal dust samples with determined parameters.

Explosion pressure $P_{e x}$ is a maximum surplus pressure that occurs during deflagration combustion of a gas, vapor or dust-air mixture in a closed vessel at an initial pressure of the mixture equal to $101.3 \mathrm{kPa}$. The pressure should be defined as the arithmetic mean using the three tests.

Combustion time $t_{1}$ is a time difference between ignition activation and culmination point.

Induction time $t_{2}$ is the time difference between ignition activation and intersection of a tangent curve with the $0 \mathrm{MPa}$ line.

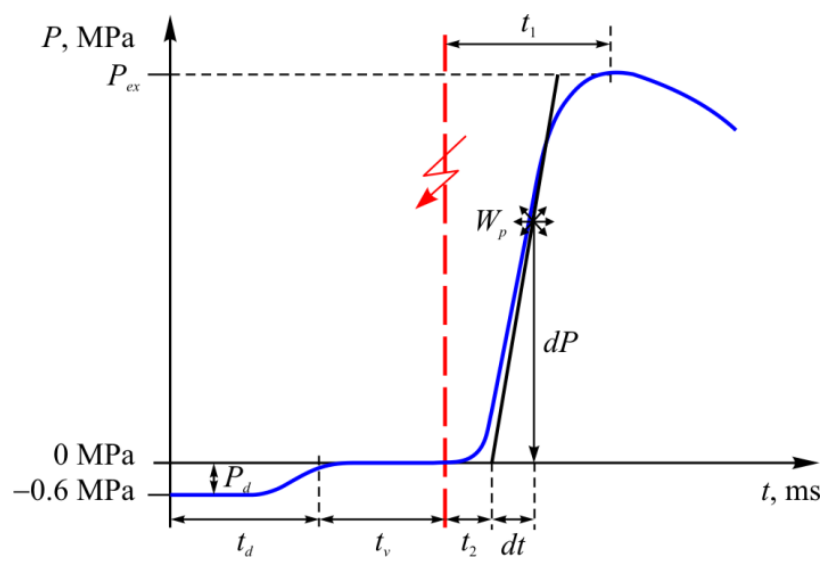

Fig. 2. Graph of pressure changes $(P, \mathrm{MPa})$ during the time $(t, \mathrm{~ms})$ of combustion of a dust/gas mixture in the explosion chamber: $P_{d}$ - rarefaction pressure of the combustion chamber; $P_{e x}-$ explosion pressure; $t_{d}$ - time delay of the exhaust valve; $t_{1}-$ combustion time; $t_{2}-$ induction time; $t_{v}$ - ignition delay time; $W_{p}-$ the inflection point in the increasing part of the pressure curve; $d P / d t$ - explosion pressure increase rate

Rarefaction pressure in the combustion chamber $P_{d}$ is the difference between the 
"preliminary vacuum" and normal pressure (standard value is $0.55-0.7 \mathrm{MPa}$ ).

Temporary retention of the exhaust valve $t_{d}$ is the time between electrical activation of the valve and beginning of pressure increase in the installation (should be in the range of 30-50 ms).

Ignition delay time $t_{v}$ influences the degree of turbulence (an important initial parameter).

$W_{p}$ - the inflection point in the increasing part of the pressure curve.

Explosion pressure increase rate $d P / d t$ is the ratio of the increment of the pressure created during the explosion in a closed vessel, to the time interval during which this increment occurred. The value of explosion pressure increase rate is used in the development of measures to ensure fire and explosion safety of technological processes. It is defined as the maximum of the tangent slope at the inflection point $W_{p}$ in the growing part of pressure increase curve in time.

\section{Results and discussion}

The results obtained were processed using the applied software. Based on the data obtained there was a plot built representing the function of change in coal dust explosion pressure on concentration and detonation burning time of a dust/gas mixture (Fig. 3a). The graphs of change in explosion pressure and explosion pressure increase rate versus time were built as well (Fig. 3b) (pressure-time).

While determining the dependence of change in explosion pressure on concentration and rate of explosion from concentration of coal dust in the volume of the blasting chamber, we applied the recommended step for the mass amount of dust necessary to create a concentration in the volume of the 20-liter sphere. For example, we applied a step not exceeding $50 \%$ of the original value for low concentrations, equal to $50 \%$ for high concentrations and more than $50 \%$ of the initial value for the last stage. In accordance with our methodology used, based on the data of $[13,18$,
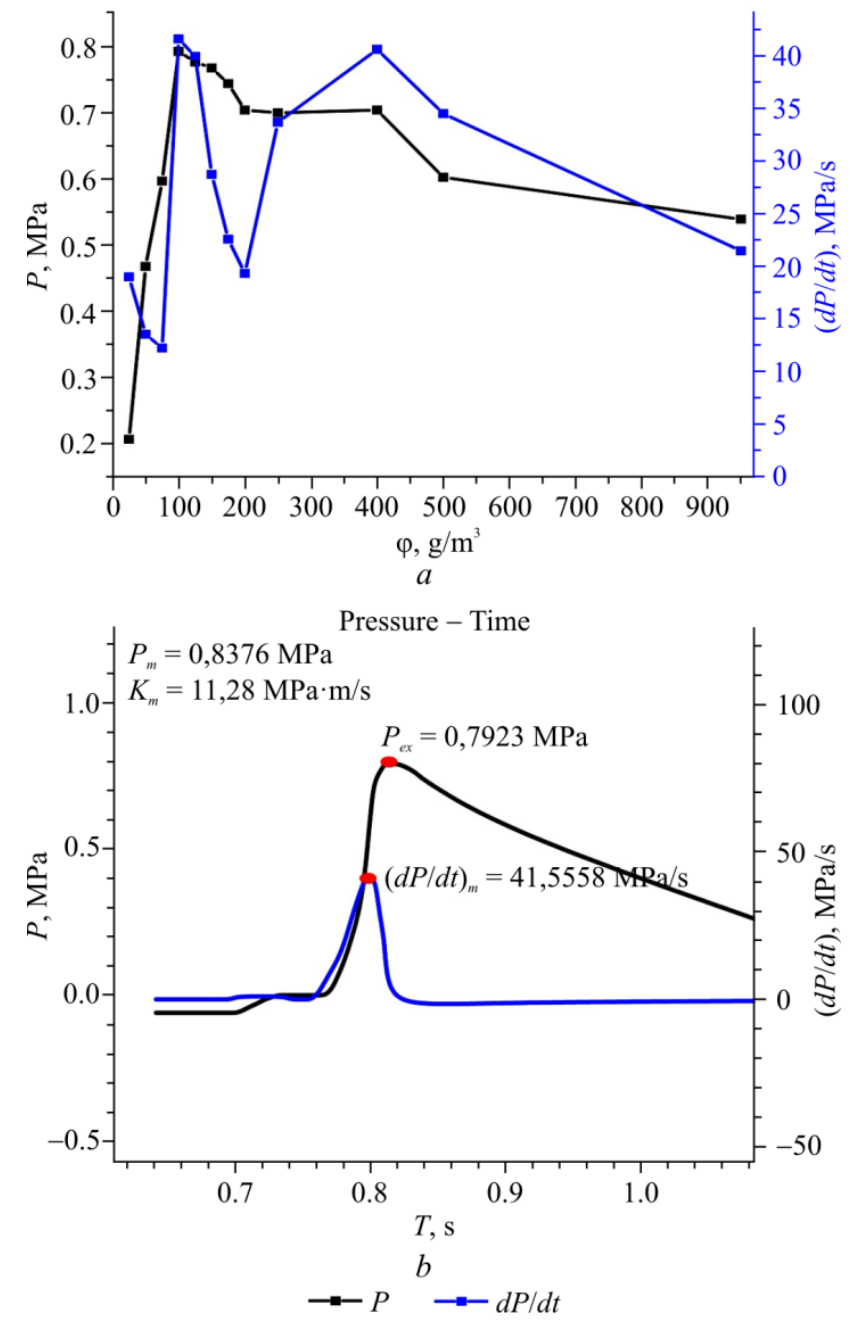

Fig. 3. Graph of explosion pressure change $P$ and explosion pressure increase rate $d P / d t: a-$ on coal dust concentration $\varphi$ in 20-liter volume of the sphere (explosion chamber); $b$ - on time $T$

19-21] and taking into account the information contained in [27-29], the results obtained are presented in the table.

According to the table, an ignition area (detonation combustion) is wide enough (from 50 to $950 \mathrm{~g} / \mathrm{m}^{3}$ ).

Results of laboratory experiments to determine the coal dust concentration influence on the explosion pressure and rate of explosion pressure increase rate are shown in Fig. $3 a$.

The analysis of Fig. 3 shows that explosion pressure increase rate hardly changes in a rather wide concentration range in particular $175-400 \mathrm{~g} / \mathrm{m}^{3}$ $(175,200,250,400)$ : from $P_{\exp }=0.74 \mathrm{MPa}$ at 
$\varphi=175 \mathrm{~g} / \mathrm{m}^{3}$ to $P_{\exp }=0.7 \mathrm{MPa}$ at $\varphi=400 \mathrm{~g} / \mathrm{m}^{3}$. Further increase in coal dust concentration in the reaction volume leads to a slow decrease in explosion pressure. There were two failures at concentration of $950 \mathrm{~g} / \mathrm{m}^{3}$ and no ignition of dustair mixture at concentration of $1000 \mathrm{~g} / \mathrm{m}^{3}$.

Results of the detonation combustion (explosion) experiment in the volume of the 20-liter sphere during its burning by a chemical igniter with the energy of $10 \mathrm{~kJ}$

\begin{tabular}{|c|c|c|}
\hline $\begin{array}{c}\text { No. of } \\
\text { expe- } \\
\text { riment }\end{array}$ & $\begin{array}{c}\text { Dust concentration, } \\
\mathrm{g} / \mathrm{m}^{3}\end{array}$ & Explosion \\
\hline 1 & 25 & No \\
\hline 2 & 50 & Yes \\
\hline 3 & 75 & Yes \\
\hline 4 & 100 & Yes \\
\hline 5 & 125 & Yes \\
\hline 6 & 150 & Yes \\
\hline 7 & 175 & Yes \\
\hline 8 & 200 & Yes \\
\hline 9 & 250 & Yes \\
\hline 10 & 400 & Once no, twice yes \\
\hline 11 & 500 & Twice no, once yes \\
\hline 12 & 600 & No \\
\hline 13 & 950 & \\
\hline 14 & 1000 & \\
\hline
\end{tabular}

While carrying out the scientific and experimental work aimed to study the dependence of change in explosion pressure increase rate on coal dust concentration, we obtained results that could not explain immediately. For example, the maximum rate of increase in pressure $(d P / d t)$ is observed at a concentration of $100 \mathrm{~g} / \mathrm{m}^{3}$ and then with a further increase in coal dust concentration it falls sharply. However, a second explosion pressure increase rate was observed starting from $200 \mathrm{~g} / \mathrm{m}^{3}$, that reached its maximum at $\varphi=400 \mathrm{~g} / \mathrm{m}^{3}$ and then slow fall slowly $d P / d t$.

As a result of the study of dust concentration influence on explosion pressure, the concentration of coal dust equal to $100 \mathrm{~g} / \mathrm{m}^{3}$ was selected for further studies (see Fig. 4) and work was continued to determine the most effective flame-extinguishing and explosive-suppressing powder compositions.
The result of processing in OriginPro software of automatically detected detonation combustion data of a dust-air aerosol of dispersion (fraction) 63-94 $\mu \mathrm{m}$ in a 20 -liter explosion chamber (sphere) is given in Fig. $3 b$.

In accordance with the methodology, three experiments with the same sample of coal dust (by mass, dispersion etc.) were performed and final graph was built presented in Fig. $3 a$.

According to the experimental data obtained by us during the KS-type coal dust detonation combustion of the Dzerzhinskiy mine, the maximum explosion pressure was uqeal to $0.7923 \mathrm{MPa}(7.9 \mathrm{~atm}$ or $792.3 \mathrm{kPa})$, i.e. $P_{\text {in }}=0.7923\left({ }^{1} P_{\min }=0.7684,{ }^{2} \mathrm{P}_{\exp }=0.7719\right.$ and $\left.{ }^{3} P_{\max }=0.8376 \mathrm{MPa}\right)$.

Pressure increase rate was $41.558 \mathrm{MPa} / \mathrm{s}$.

The transformation coefficient $K_{\mathrm{m}}$ calculated by the applied software of the laboratory installation was equal to $11.28 \mathrm{MPa} \cdot \mathrm{m} / \mathrm{s}$.

According to the data presented in [17], if the transformation coefficient is known then it is possible to calculate the explosion pressure increase rate in any volumes, including mine workings.

The results obtained conform well with previously determined data given in $[19,24,25$, 29, 30].

Considering the fact that during the process of determination (investigation) of explosion pressure increase rate a number of difficulties was obtained (see the description of Fig. 3 above), the more attention will be paid for further scientific and research work.

\section{Conclusions}

1. Explosive and dangerous characteristics of KS-type coal dust of Moshchny seam Dzerzhinskiy are studied. The maximum recorded explosion pressure was $0.8376 \mathrm{MPa}\left(P_{\mathrm{m}}\right)$. It was confirmed that dust fractions with a dispersion of 63-94 $\mu \mathrm{m}$ at a concentration equal to $100 \mathrm{~g} / \mathrm{m}^{3}$ have a large maximum explosion pressure. 
2. The second growth (increase) in explosion pressure rate could be observed in the region of high concentrations. The maximum explosion pressure increase rate was $d P / d t=41.558 \mathrm{MPa} / \mathrm{s}$ at $\varphi=100 \mathrm{~g} / \mathrm{m}^{3}$. The second rate increase is observed from $\varphi=200 \mathrm{~g} / \mathrm{m}^{3}$ to $\varphi=400 \mathrm{~g} / \mathrm{m}^{3}$. Herewith $d P / d t=40.5 \mathrm{MPa} / \mathrm{s}$, which is lower the peak at $\varphi=100 \mathrm{~g} / \mathrm{m}^{3}$. We consider that it is reasonable to continue studying the behavior of explosion pressure increase rate depending on concentration of coal dust in the reaction volume of the installation.
3. It is determined that because of the large spread of $d P / d t$ values (which is more than $15 \%$ ), there is a need to determine the arithmetic mean for the data of more than three measurements or to determine the reason for the variance of values and develop measures to eliminate it.

4. In our opinion it necessary to continue work in this direction and in order to identify an effective fire-extinguishing and explosivesuppression composition for $\varphi=100 \mathrm{~g} / \mathrm{m}^{3}$ to carry out the investigations both in the air environment and in medium containing methane.

\section{References}

1. Kudinov Iu.V., Volodin A.V. O mekhanizme vzryva ugol'noi pyli [On the mechanism of coal dust explosion]. Sposoby $i$ sredstva sozdaniia bezopasnykh $i$ zdorovykh uslovii truda v ugol'nykh shakhtakh, 2013, 1(31).

2. Promyshlennaia bezopasnost' predpriiatii mineral'no-syr'evogo kompleksa $\mathrm{v}$ XXI veke [Industrial safety of enterprises of the mineral and raw materials complex in the 21st century]. Bezopasnost' truda v promyshlennosti, 2017, no.1, pp.82-87.

3. Kaliakin S.A., Bulgakov Iu.F. Pozharovzryvoopasnost' otlozhenii ugol'noi pyli [Fire and explosion hazard of coal dust deposits]. Nauchnyi vestnik NIIGD Respirator, 2012, no.1, pp.14-27.

4. Kaliakin S.A., Shevtsov N.R., Kupenko I.V. Sozdanie effektivnoi sistemy vzryvozashchity ugol'nykh shakht [Development of the effective system for explosion protection of coal mines]. Ugol' Ukrainy, 2012, no.2, pp.24-30.

5. Gogo V.B. Razvitie teorii vzryva pyleugol'nogo aerozolia [Development of the theory of the explosion of coal dust aerosol]. Informatsionnye tekhnologii $v$ nauchnykh issledovaniiakh $i$ uchebnom protsesse. Sbornik nauchnykh trudov vtoroi mezhdunarodnoi konferentsii. Alchevsk, Lugansk, 2006, spetsvypusk, pp.29-34.

6. Rodionov V.A., Pikhkonen L.V., Zhikharev S.Ia. Analiz primeneniia metodov termicheskogo analiza dlia otsenki vzryvopozharoopasnykh svoistv kamennogo uglia Sokolovskogo mestorozhdeniia [Analyzing application methods of thermal analysis for evaluation of explosive properties of Sokolovsky deposit coal]. Izvestiia Tul'skogo gosudarstvennogo universiteta. Nauki o Zemle, 2017, no.3, pp.84-93.

7. Airuni A.T., Klebanov F.S., Smirnov O.V. Vzryvoopasnost' ugol'nykh shakht [Explosiveness of coal mines]. Moscow, Gornoe delo, Kimmeriiskii tsentr, 2011, 264 p.

8. Ugol'naia promyshlennost'. Informatsionnyi biulleten' Federal'noi sluzhby po ekologicheskomu, tekhnologicheskomu i atomnomu nadzoru [Coal industry. Information Bulletin of the Federal Service for Environmental, Technological and Nuclear Supervision], 2016, no.4 (85), pp.1-7.

9. Gordienko V.M., Vogman L.P., Gorshkov V.I. et al. Obespechenie pozharnoi bezopasnosti proizvodstvennykh ob"ektov. Issledovanie i razrabotka normativnykh dokumentov FGBU VNIIPO MChS Rossii $\mathrm{v}$ oblasti preduprezhdeniia pozharov i vzryvov [Provision of fire safety of production facilities. Research and development of normative documents of FBSI VNIIPO of the EMERCOM of Russia the field of prevention of fires and explosions]. Occupational Safety in Industry, 2017, no.6, pp.5-20. DOI:10.24000/0409-2961-2017-6-5-20 
10. Lebetski K.A., Romanchenko S.B. Pylevaia vzryvoopasnost' gornogo proizvodstva [Dust explosiveness of mining]. Moscow, Gornoe delo, Kimmeriiskii tsentr, 2012, vol.6, book 10, 464 p. (Biblioteka gornogo inzhenera).

11. Netsepliaev M.I., Liubimova A.I., Petrukhin P.M. et al. Bor'ba so vzryvami ugol'noi pyli v shakhtakh [Control of the coal dust explosions in mines]. Moscow, Nedra, 1992, 300 p.

12. Rashevskii V.V, Artem'ev V.B., Siliutin S.A. Kachestvo uglei OAO "SUEK" [Quality of coals of SUEK OJSC]. Moscow, Kuchkovo pole, 2011, vol.5, book 1, 576 p. (Biblioteka gornogo inzhenera).

13. Pikhkonen L.V., Rodionov V.A., Zhikharev S.Ia. Opredelenie vzryvopozharoopasnykh svoistv kamennogo uglia Leninsk-Kuznetskogo kamennougol'nogo mestorozhdeniia [Determination research of fire and explosion hazardous properties for hard coal at the Prokopyevsk coal field of the Leninsk-Kuznetskiy coal field]. Izvestiia Tul'skogo gosudarstvennogo universiteta. Nauki o zemle, 2017, iss.3, pp.74-84

14. Sapko M., Weiss E., Cashdollar K., Zlochower I. Experimental mine and laboratory dust explosion research at NIOSH. Journal of Loss Prevention in the Process Industries, 2000, vol. 13, iss.3-5, pp.229-242. DOI: 10.1016/S0950-4230(99)00038-8

15. Rodionov V.A., Pikhkonen L.V., Zhikharev S.Ya. Dispersion of the G-type coal dust of the Vorgashorskoe field and its influence on the thermal destruction process. Perm Journal of Petroleum and Mining Engineering, 2017, vol.16, n.4, pp.350-356. DOI: $10.15593 / 2224-9923 / 2017.4 .6$

16. Tolchinskii E.N., Kiselev V.A. Vliianie dispersnogo sostava pyli prirodnogo tverdogo topliva na ee vzryvoopasnye svoistva [Influence of the dispersion composition of the dust of natural solid fuel on its explosive properties]. Elektricheskie stantsii, 2001, no.5, pp.11-16.

17. Kolesnichenko I.E., Artem'ev V.B., Kolesnichenko E.A., Cherechukin V.G., Liubomishchenko E.I. Teoriia goreniia i vzryva metana i ugol'noi pyli [The theory of combustion and explosion of methane and coal dust]. Ugol', 2016, no.6, pp.30-35. DOI:http://dx.doi.org/ 10.18796/0041-5790-2016-6-30-35

18. Zhikharev S.Ia., Pikhkonen L.V., Rodionov V.A. Issledovanie vzryvopozharoopasnykh svoistv kamennogo uglia Prokop'evskogo mestorozhdeniia kuznetskogo ugol'nogo basseina [Research of fire and explosion hazardous properties for hard coal at the Prokopyevsk coal field of the Kuznetsk coal basin]. Izvestiia Tul'skogo gosudarstvennogo universiteta. Nauki o zemle, 2017, iss.3, pp.65-74.

19. Determination of explosion characteristics of dust clouds Part 1: Determination of the maximum explosion pressure $P_{\max }$ of dust clouds British Standard BS EN 14034-1:2004+A1:2011, available at: http://base.iepi.com.cn/download/ Standards/CEN/EN \%2014034-1-2004 \%20Determination \%20of \%20the \%20maximum $\% 20$ explosion \%20pressure \%20Pmax \%20of \%20dust \%20clouds.pdf (accessed 12 September 2017).

20. Determination of explosion characteristics of dust clouds. Part 2: Determination of the maximum rate of explosion pressure rise $(d P / d t)_{\max }$ of dust clouds BS EN 14034-2:2006+A1:2011, available at: http://docs.cntd.ru/document/43180 2696 (accessed 10 September 2017).

21. Determination of explosion characteristics of dust clouds Part 3: Determination of the lower explosion limit LEL of dust clouds BS EN 140343:2006+A1:2011, available at: http://docs.cntd.ru/ document/431804881 (accessed 10 September 2017).

22. Standard test method for minimum explosible concentration of combustible dusts ASTM E1515, available at: http://docs.cntd.ru/ document/431812540 (accessed 10 September 2017).

23. Standard test method for minimum for explosibility of dusts clouds ASTM E1226-10, available at: http://docs.cntd.ru/document/4619 10142 (accessed 10 September 2017).

24. Kühner A.G. Operating instructions for the 20 litre apparatus 5.0. Basel, Switzerland, CibaGeigy AG, 1994. 
25. Li Qingzhao, Zhai Cheng, Wu Haijin. Investigation on coal dust explosion characteristics using $20 \mathrm{~L}$ explosion sphere vessels. Journal of China Coal Society, 2011, 36 p.

26. Siwek R. Experimental methods for the determination of explosion characteristics of combustible dust. 3 International Symposium on Lose Prevention and Safety Promotion in the Process Industries. Basel, 1980, vol.3.

27. Danilov A.G., Grachev E.A., Kul'chitskii S.V., Galiev M.G. Svoistva i paramerty, opredeliaiushchie vzryvchatost' ugol'noi pyli [Properties and parameters, which determine the explosiveness of coal dust]. Evraziiskii nauchnyi zhurnal, 2015, no.8, pp.12-17.

28. Dastidar P., Amyotte J., Going, K. Chartathi, Inerting of coal dust explosions in laboratory - and intermediate-scale chambers.
Fuel, 2001, vol.80, iss.11, pp.1593-1602. DOI: 10.1016/S0016-2361(01)00038-2

$$
\text { 29. GOST 12.1.044-89 (ISO 4589-84) }
$$

Sistema standartov bezopasnosti truda. Pozharovzryvoopasnost' veshchestv i materialov. Nomenklatura pokazatelei i metody ikh opredeleniia (s Izmeneniem no.1) [Occupational safety standards system. Fire and explosion safety of matter and materials. Nomenclature of indicators and methods of their determination (with Change no.1)], available at: http://docs.cntd.ru/document/1200004802 (accessed 10 September 2017).

30. Korol'chenko A.Ia., Korol'chenko D.A. Pozharovzryvoopasnost' veshchestv i materialov i sredstva ikh tusheniia [Fire and explosion hazard of matter and materials and means of their suppression. Reference book: in 2 parts]. Spravochnik v 2 chastiakh. Moscow, Pozhnauka, 2004, 713 p.

\section{Библиографический список}

1. Кудинов Ю.В., Володин А.В. О механизме взрыва угольной пыли // Способы и средства создания безопасных и здоровых условий труда в угольных шахтах. - 2013. - 1(31).

2. Промышленная безопасность предприятий минерально-сырьевого комплекса в XXI веке // Безопасность труда в промышленности. - 2017. № 1. - С. 82-87.

3. Калякин С.А., Булгаков Ю.Ф. Пожаровзрывоопасность отложений угольной пыли // Научный вестник НИИГД Респиратор. - 2012. № 1. - C. 14-27.

4. Калякин С.А., Шевцов Н.Р., Купенко И.В. Создание эффективной системы взрывозащиты угольных шахт // Уголь Украины. - 2012. № 2. - C. 24-30.

5. Гого В.Б. Развитие теории взрыва пылеугольного аэрозоля // Информационные технологии в научных исследованиях и учебном процессе: сб. науч. тр. 2-й междунар. конф. / ДонГТУ. - Алчевск: ДонГТУ; Луганск: ЛУПУ, 2006. - Спецвып. - С. 29-34.
6. Родионов В.А., Пихконен Л.В., Жихарев С.Я. Анализ применения методов термического анализа для оценки взрывопожароопасных свойств каменного угля Соколовского месторождения // Известия Тульского государственного университета. Науки о Земле. 2017. - № 3. - С. 84-93.

7. Айруни А.Т., Клебанов Ф.С., Смирнов О.В. Взрывоопасность угольных шахт. - М.: Горное дело; Киммерийский центр, 2011. - 264 с.

8. Угольная промышленность: Информационный бюллетень Федеральной службы по экологическому, технологическому и атомному надзору / Управление по надзору в угольной промышленности. - 2016. - № 4(85). - С. 1-7.

9. Обеспечение пожарной безопасности производственных объектов. Исследование и разработка нормативных документов ФГБУ ВНИИПО МЧС России в области предупреждения пожаров и взрывов / В.М. Гордиенко, Л.П. Вогман, В.И. Горшков [и др.] // Безопасность труда в промышленности - 
Occupational Safety in Industry. - 2017. - № 6. C. 5-20. DOI:10.24000/0409-2961-2017-6-5-20

10. Лебецки К.А., Романченко С.Б. Пылевая взрывоопасность горного производства. - М.: Горное дело; Киммерийский центр, 2012. - Т. 6 : Промышленная безопасность, кн. 10. - 464 с. (Серия «Библиотека горного инженера»).

11. Борьба со взрывами угольной пыли в шахтах / М.И. Нецепляев, А.И. Любимова, П.М. Петрухин [и др.]. - М.: Недра, 1992. - 300 с.

12. Рашевский В.В, Артемьев В.Б., Силютин С.А. Качество углей ОАО «СУЭК». М.: Кучково поле, 2011. - Т. 5, кн. 1. - 576 с. (Серия «Библиотека горного инженера»).

13. Пихконен Л.В., Родионов В.А., Жихарев С.Я. Определение взрывопожароопасных свойств каменного угля Ленинск-Кузнецкого каменноугольного месторождения // Известия Тульского государственного университета. Науки о земле. - 2017. - Вып. 3. - С. 74-84.

14. Experimental mine and laboratory dust explosion research at NIOSH / M. Sapko, E. Weiss, K. Cashdollar, I. Zlochower // Journal of Loss Prevention in the Process Industries. 2000. - Vol. 13, iss. 3-5. - P. 229-242. DOI: 10.1016/S0950-4230(99)00038-8

15. Родионов В.А., Пихконен Л.В., Жихарев С.Я. Дисперсность каменноугольной пыли марки Ж Воргашорского месторождения и ее влияние на процесс термической деструкции // Вестник Пермского национального исследовательского политехнического университета. Геология. Нефтегазовое и горное дело. - 2017. - Т. 16, № 4. C. $350-56$. DOI: $10.15593 / 2224-9923 / 2017.4 .6$

16. Толчинский Е.Н., Киселев В.А. Влияние дисперсного состава пыли природного твердого топлива на ее взрывоопасные свойства // Электрические станции (ежемесячный производственно-технический журнал). 2001. - № 5. - C. 11-16.

17. Теория горения и взрыва метана и угольной пыли / И.Е. Колесниченко, В.Б. Артемьев, Е.А. Колесниченко, В.Г. Черечукин, Е.И. Любо- мищенко // Уголь. - 2016. - № 6. - С. 30-35. DOI:http://dx.doi.org/10.18796/0041-5790-2016-6-30-35

18. Жихарев С.Я., Пихконен Л.В., Родионов В.А. Исследование взрывопожароопасных свойств каменного угля Прокопьевского месторождения кузнецкого угольного бассейна // Известия Тульского государственного университета. Науки о земле. - 2017. - Вып. 3. C. 65-74.

19. Determination of explosion characteristics of dust clouds. Part 1: Determination of the maximum explosion pressure $P_{\max }$ of dust clouds British Standard BS EN 14034-1:2004+A1:2011 [Электронный pecypc]. - URL: http:// base.iepi.com.cn/download/Standards/CEN/EN \%2014034-1-2004 \%20Determination \%20of $\% 20$ the $\% 20$ maximum \%20explosion \%20pressure \%20Pmax \%20of \%20dust \%20clouds.pdf (дата обращения: 12.09.2017).

20. Determination of explosion characteristics of dust clouds. Part 2: Determination of the maximum rate of explosion pressure rise $(d P / d t)_{\max }$ of dust clouds BS EN 14034-2:2006+A1:2011 [Электронный ресурс]. URL: http://docs.cntd.ru/ document/431802696 (дата обращения: 10.09.2017).

21. Determination of explosion characteristics of dust clouds Part 3: Determination of the lower explosion limit LEL of dust clouds BS EN 140343:2006+A1:2011 [Электронный ресурс]. - URL: http://docs.cntd.ru/document/431804881 (дата обращения: 10.09.2017).

22. Standard test method for minimum explosible concentration of combustible dusts ASTM E1515-14 [Электронный ресурс]. - URL: http://docs.cntd.ru/document/431812540 (дата обращения: 10.09.2017).

23. Standard test method for minimum for explosibility of dusts clouds ASTM E1226-10 [Электронный ресурс]. - URL: http://docs.cntd.ru/ document/461910142 (дата обращения: 10.09.2017).

24. Kühner A.G. Operating instructions for the 20 litre apparatus 5.0. - Basel, Switzerland: CibaGeigy AG, 1994. 
25. Li Qingzhao, Zhai Cheng, Wu Haijin. Investigation on coal dust explosion characteristics using $20 \mathrm{~L}$ explosion sphere vessels // Journal of China Coal Society. $-2011 .-36$ p.

26. Siwek R. Experimental methods for the determination of explosion characteristics of combustible dust // 3-d International Symposium on Lose Prevention and Safety Promotion in the Process Industries. - Basel, 1980. - Vol. 3.

27. Свойства и парамерты, определяющие взрывчатость угольной пыли / А.Г. Данилов, Э.А. Грачев, С.В. Кульчицкий, М.Г. Галиев // Евразийский научный журнал. - 2015. - № 8. C. $12-17$.

28. Dastidar P., Amyotte J., Going K. Chartathi, Inerting of coal dust explosions in laboratory - and intermediate-scale chambers // Fuel. - 2001. - Vol. 80, iss. 11. - P. 1593-1602. DOI: 10.1016/S0016-2361(01)00038-2

$$
\text { 29. ГОСТ 12.1.044-89 (ИСО 4589-84) }
$$

Система стандартов безопасности труда (ССБТ). Пожаровзрывоопасность веществ материалов. Номенклатура показателей и методы их определения (с изменением № 1) [Электронный pecypc]. - URL: http://docs.cntd.ru/document/ 1200004802 (дата обращения: 10.09.2017).

30. Корольченко А.Я., Корольченко Д.А. Пожаровзрывоопасность веществ и материалов и средства их тушения: справочник: в 2 ч. 2-е изд., прераб. и доп. - М.: Пожнаука, 2004. $-713 \mathrm{c}$.

Please cite this article in English as:

Rodionov V.A., Abiev Z.A., Zhikharev S.Ya. Methodology for investigation of stone dust combustion and detonation processes in mining. Perm Journal of Petroleum and Mining Engineering, 2018, vol.17, no.1, pp.50-59. DOI: 10.15593/2224-9923/2018.1.5

Просьба ссылаться на эту статью в русскоязычных источниках следующим образом:

Родионов В.А., Абиев З.А., Жихарев С.Я. Методика исследования процессов горения и детонации каменноугольной пыли в горных выработках // Вестник Пермского национального исследовательского политехнического университета. Геология. Нефтегазовое и горное дело. - 2018. - Т.17, №1. - C.50-59. DOI: 10.15593/2224-9923/2018.1.5 